\begin{tabular}{|c|c|c|}
\hline & Int.J.Curr.Microbiol.App.Sci (2021) 10(12): 240-250 & \\
\hline & $\begin{array}{l}\text { International Journal of Current Microbiology and Applied Sciences } \\
\text { ISSN: 2319-7706 Volume } 10 \text { Number } 12 \text { (2021) } \\
\text { Journal homepage: http://www.ijcmas.com }\end{array}$ & 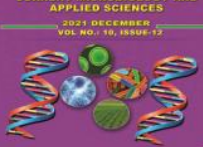 \\
\hline $\begin{array}{l}\text { EXCELLENT } \\
\text { PUBLISHERS }\end{array}$ & & \\
\hline
\end{tabular}

Original Research Article https://doi.org/10.20546/ijcmas.2021.1012.028

\title{
Effect of Growth Regulators and Micronutrients on Growth and Yield of Pleurotus sajor-caju
}

\author{
D. D. Godse, C. T. Kumbhar", A. C. Jadhav and L. S. Shitole \\ Department of Plant Pathology and Agricultural Microbiology, College of Agriculture, \\ Pune-411 005, Maharashtra, India \\ *Corresponding author
}

\section{Keywords}

Pleurotus sajor-

caju, Growth

regulators,

Micronutrients

\section{Article Info}

Received:

11 November 2021

Accepted:

06 December 2021

Available Online:

10 December 2021
The present investigation was conducted to study the effect of various growth regulators and micronutrients on growth and yield of Pleurotus sajor-caju. Results of the research explicitly indicated that the growth regulators and micronutrients experimented at different concentrations, targeting at stimulating growth and sporophore yield of Pleurotus sajor-caju, displayed significantly diverse response to in vitro colony diameter of the fungus, days required for spawn run, pinhead formation, first harvest of sporophores, yield of sporophores and biological efficiency. However, among the growth regulators used, gibberellic acid (GA) @ 20 and 15 ppm significantly improved the colony diameter $(90$ and $89.98 \mathrm{~mm}$ ) in in vitro study; reduced the period required for spawn running (13 and 13.5 days), pinhead formation (16 and 16.5), and first harvest (18.5 and 19); augmented the total sporophore yield ( 858.25 and $855 \mathrm{~g} / \mathrm{kg}$ dry substrate) and biological efficiency (85.83 and $85.5 \%$ ). Mixture of micronutrients was ineffective in augmenting the foregoing traits. From the present investigation it is concluded that, spraying of gibberellic acid at 20 and 15 ppm concentrations on cultivation substrate, at the time of spawning, is highly beneficial for obtaining maximum yield of Pleurotus sajor-caju.

\section{Introduction}

In India, three mushrooms are commercially cultivated: Agaricus bisporus (white button mushroom), Pleurotus spp. (oyster mushroom), and Volvariella spp. (tropical mushroom) (Chadha, 1992). Mushrooms are popular because of their excellent flavour, low calorie count, high protein content, B vitamins and minerals. Mushrooms are high in nonstarchy carbohydrates, dietary fibre, protein, minerals, and vitamins (Kulshreshtha et al., 2009).

In India, mushrooms are cultivated in different states amongst which, Punjab is the largest producer of Agaricus, followed by Tamil Nadu which produces Agaricus, Pleurotus, Volvariella and Calocybe mushrooms and, Rajasthan produces Agaricus and Pleurotus mushrooms (Singh and Prasad, 2012). Mushroom production in India was 441 tonnes 
in 2016-17, and it climbed to 487 tonnes in 2017-18 (Anonymous, 2018).

Pleurotus spp., also known as "oyster mushroom" or "dhingri," presently rank second among the world's farmed mushrooms. These mushrooms are highly effective in lowering dangerous plasma lipids, lowering the risk of atherosclerosis and other cardiovascular and artery problems. Pleurotus spp. belongs to the Agaricomycetes class, the Agaricales order, and the Pleurotaceae family. Pleurotus florida (Mont.) Singer, Pleurotus eous (Berk) Sacc., Pleurotus ostreatus (Jacq.) Kummer, Pleurotus sajor-caju (Fr.) Singer, Pleurotus flabellatus Sacc., Pleurotus pulmonarius (Fr.) Quel., Pleurotus cystidiosus O. K. Mill., have been examined by numerous scientists for their antioxidant, antimicrobial and nutritional profile because of the excellent medicinal and culinary properties of this genus. Pleurotus spp. have a large quantity of moisture (90.8 per cent), whereas fresh as well as dry oyster mushrooms are rich in carbohydrates (57.6 per cent), proteins (30.4 per cent), fibre (8.7 per cent), fat (2.2 per cent) and ash (9.8 per cent) with 345 kcal energy value on $100 \mathrm{~g}$ dry weight basis; while they contain vitamins such as niacin $(108.7 \mathrm{mg})$, thiamin $(4.8 \mathrm{mg})$ and riboflavin $(4.7 \mathrm{mg})$ and minerals like calcium (98 mg), phosphorous (476 mg), ferrous $(8.5 \mathrm{mg}$ ) and sodium (61 $\mathrm{mg}$ ) on $100 \mathrm{~g}$ dry weight basis (Pandey and Ghosh, 1996).

Improvement in cultivation technology of mushroom is anincessant process. Researchers working in the field of mushrooms attempt to augment yield of mushrooms by using innovative ideas and techniques. Use of plant growth regulators for mushroom production is one of them. Plant growth regulators, also known as phytohormones, are organic chemical molecules that, when given in small amounts, influence the growth of plants (Prajapati et al., 2015). Different concentrations of growth regulators affect mushroom size and yield (Charles, 1986). Growers would gain benefit from fewer but larger fruiting bodies or fewer but more numerous fruiting bodies, resulting in higher yield.

Earlier investigators have reported significant role of growth regulators in mushroom cultivation. Mukhopadhyay et al., (2005) investigated that the plant growth regulators such as gibberellic acid (GA), indole-3-acetic acid (IAA) and kin boosted the biomass production of Pleurotus sajor-caju by 15-26 per cent, while also increasing the protein content of the mycelia at varied doses. Some researchers reported that in vitro mushroom mycelial colony multiplication is also aided by plant growth regulators and medium (Maniruzzaman, 2004; Shukla, 1995; Chodchoi, 1986). Moreover, some researchers also have investigated effects of micronutrients on growth and yield of mushrooms. Atri and Guleria (2013) documented the highest vegetative growth $(7.46 \mathrm{mg} / \mathrm{ml})$ of Lentinus cladopus at a $1 \mathrm{ppm}$ iron concentration. Bearing in mind the importance of plant growth regulators and micronutrients on mushroom yield, the present experiment was conducted to determine the influence of growth regulators and micronutrients at different dosages on the growth and yield of Pleurotus sajor-caju.

\section{Materials and Methods}

The present investigation was conducted at the All India Coordinated Mushroom Improvement Project, College of Agriculture, Pune. Pure culture required for spawn production of Pleurotus sajor-caju was obtained from the Mycologist, All India Coordinated Mushroom Improvement Project, College of Agriculture, Pune. Various growth regulators viz., gibberellic acid (GA), indole3-acetic acid (IAA) and indole-3-butyric acid 
(IBA) and, mixture of micronutrients consisting of iron (Fe) 2.5\% EDTA, manganese (Mn) 1\% EDTA, zinc (Zn) 3\% EDTA, copper (Cu) $1 \%$ EDTA, molybdenum (Mo) $0.1 \%$ and boron (B) $0.5 \%$ at different dosages were appraised in the present experimentation in order to find out the most effective growth regulator and micronutrient mixture and their dosages for augmenting the mycelial growth, sporocarp growth and yield of Pleurotus sajor-caju.

Preparation of solutions of growth regulators and micronutrients

For preparation of solutions of growth regulators viz., gibberellic acid (GA), indole3-acetic acid (IAA) and indole-3-butyric acid (IBA) of 10,15 and $20 \mathrm{ppm}$ concentrations, $1.2 \mathrm{mg}, 1.8 \mathrm{mg}$ and $2.4 \mathrm{mg}$ of each of the growth regulator, respectively, were added separately in $5 \mathrm{ml}$ of $1 \mathrm{~N} \mathrm{NaOH}$ solution. These solutions were further added separately to $120 \mathrm{ml}$ sterilized water.

For preparation of solutions of mixture of micronutrients of 1,2 and $5 \mathrm{ppm}$ concentrations, $0.12 \mathrm{mg}, 0.24 \mathrm{mg}$ and $0.6 \mathrm{mg}$ of mixture of micronutrients, respectively, were added separately in $5 \mathrm{ml}$ of $1 \mathrm{~N} \mathrm{NaOH}$ solution. These solutions were further added separately to $120 \mathrm{ml}$ sterilized water. For preparation of the solutions sterile glasswares were utilized and all the procedures were performed under aseptic conditions.

Influence of growth regulators and micronutrients on in vitro colony diameter of Pleurotus sajor-caju

To assess the effect of growth regulators and micronutrients on mycelial growth of Pleurotus sajor-caju, a basal medium (malt extract medium) was prepared and $50 \mathrm{ml}$ of it was placed in each of the conical flasks of 250 $\mathrm{ml}$ capacity. The medium was sterilized for 15 minutes in an autoclave at $15 \mathrm{lb}$ pressure $\left(121^{\circ} \mathrm{C}\right)$. The sterilized flasks were then transferred to laminar air flow cabinet. After the medium was cooled to $40-45^{\circ} \mathrm{C}$ and mixed well by steady stirring, $5 \mathrm{ml}$ of each stock solution of the growth regulators viz., gibberellic acid (GA), indole-3-acetic acid (IAA) and indole-3-butyric acid (IBA) of 10, 15 , and $20 \mathrm{ppm}$ concentrations was introduced with the use of a sterile pipette into two flasks for individual treatment.

Further, for each treatment, $20 \mathrm{ml}$ of the medium was placed into each sterilized Petri plates and allowed to solidify. Then, using a sterilized cork borer, standard mycelial bits of $5 \mathrm{~mm}$ diameter were removed from the peripheral growth of a pure culture of Pleurotus sajor-caju.

The bits were aseptically transferred to culture plates, with the mycelial growth side of the bit touching the media in the sterilized Petri plates. The Petri plates were then incubated at $25 \pm 2^{\circ} \mathrm{C}$ for 9 days and observations on mycelial growth were recorded. The diameter of the colony was measured using a measuring scale, and the average diameter was estimated for statistical analysis.

\section{Spawn production}

Wheat grain based spawn of Pleurotus sajorcaju was prepared by the method given by Garcha and Kalra (1979).

\section{Substrate preparation and sterilization}

For cultivation of Pleurotus sajor-caju, wheat straw was used as substrate. The wheat straw was filled in gunny bags and soaked into 1001 aqueous solution containing appropriate quantity of bavistin $(7.5 \mathrm{~g})$ and formalin (125 $\mathrm{ml}$ ) for 16-18 hours. After soaking for whole night, the next morning excess water was drained off. 


\section{Disinfection of mushroom house}

The spawning, spawn running, and cropping rooms were cleaned properly and washed with clean tap water. The rooms were subsequently sprayed with bavistin at a $10 \%$ dosage on a daily basis for four days. The rooms were also fumigated for 48 hours with $2 \%$ formaldehyde.

\section{Preparation of mushroom beds}

The spawning was carried out in a room that had been pre-fumigated (48 h with $2 \%$ formaldehyde). The first layer of the substrate (approximately of $5 \mathrm{~cm}$ thick) was given at the base of the polythene bags of size $45 \mathrm{~cm}$ x 55 $\mathrm{cm}$ (100 gauge) and the spawning was done uniformly over this layer. A second layer (approximately of $5 \mathrm{~cm}$ thickness) was given over this and solution of growth regulator/micronutrients was sprayed uniformly on surface of the substrate layer with the help of hand-sprayer, as per the treatments. After application of growth regulators/micronutrients, a next layer of the substrate (approximately $5 \mathrm{~cm}$ thick) was given and spawning was done. In this manner, rest of the layers of the substrate were given and finally the mouths of bags were closed with thread. There were 25-30 pinhole perforations all over the bag for substrate ventilation. At the same time, a few pinholes were made in the bottom of the bag for drainage. Each bag held $3.5 \mathrm{~kg}$ of wet straw (one kg dry straw). After spawning, the bags were placed in a permanent mushroom house and incubated in the dark at a temperature of $24-28^{\circ} \mathrm{C}$. During the spawn run, no light or cross ventilation were permitted.

\section{Crop management}

The polythene bags were removed after the spawn had fully impregnated the substrate with the fungal mycelium, exposing the substrate surface for the initiation of sporophores. These were then hanged on hangers in the mushroom house's cropping room to fruit. Water was sprayed on the compact cylinder mass of the substrate twice a day to keep them moist. During the experiment, the temperature in the cropping room varied between $22-28^{\circ} \mathrm{C}$. The cropping room's humidity was kept at 85-90 per cent by spraying water on the walls and floor on a regular basis. Two to three hours of light (supplied by a fluorescent lamp of 40 watts) and 2-3 hours of cross ventilation per 24 hours (given by opening doors and windows) were provided for cropping.

\section{Harvesting}

A day before harvesting, watering was stopped and the sporophores were harvested before spore shedding. The weight of sporophores was noted soon after harvesting.

\section{Observations}

Data recorded included the days required for spawn run, days required for pinhead formation, days required for first harvest, sporophore yield and biological efficiency.

\section{Statistical analysis}

The data obtained from the trial were statistically analysed in Completely Randomized Design as per the procedure described by Panse and Sukhatme (1985).

\section{Results and Discussion}

Influence of growth regulators and micronutrients on in vitro colony diameter of Pleurotus sajor-caju

Data pertaining to in vitro effect of different growth regulators and micronutrients on mycelial growth of Pleurotus sajor-caju, 
recorded at 9 days after inoculation (DAI), clearly indicated that gibberellic acid (GA) 20 ppm had the highest mycelial colony diameter of $90.00 \mathrm{~mm}$, followed by GA $15 \mathrm{ppm}$, which had the colony diameter of $89.98 \mathrm{~mm}$ (Table 1). However, colony diameter recorded with both the treatments differed non-significantly, which clearly substantiated that GA at 20 and 15 ppm had identical effect in augmenting the mycelial growth of $P$. sajor-caju. Thus, GA at these two concentrations was found to be significantly superior over the rest growth regulators and micronutrients tried in the investigation in improving mycelial growth of $P$. sajor-caju. The next treatments in order of efficacy were indole-3-acetic acid (IAA) 20 ppm, indole-3-butyric acid (IBA) 20 ppm, IBA $15 \mathrm{ppm}$, GA $10 \mathrm{ppm}$, micronutrient mixture $1 \mathrm{ppm}$ and IBA $10 \mathrm{ppm}$, which recorded colony diameter of 80.70, 80.60, $80.45,80.32,80$ and $70.95 \mathrm{~mm}$, respectively. Significantly least colony diameter of $50 \mathrm{~mm}$ was observed in control plates.

Results of the present experimentation evidently showed that gibberellic acid had the first-rated effect in influencing mycelial growth of $P$. sajor-caju. These results are in agreement with those of Pal et al., (2013) who found the highest mycelial growth in GA incorporated medium and the least in 2, 4-D incorporated medium.

\section{Days Required for Spawn Run}

The data depicted in Table 2 regarding effect of various growth regulators and micronutrients on days required for completion of spawn run noticeably showed significant variation in days required for spawn run.

The days required for completion of spawn run with different treatments of growth regulators and micronutrients ranged between 13.00 and 18.50 days in all beds of Pleurotus sajor-caju. However, gibberellic acid (GA) applied to the cultivation substrate at $20 \mathrm{ppm}$ required the lowest period of 13 days for completion of spawn run. This was closely followed by application of GA at $15 \mathrm{ppm}$, which took 13.5 days for completion of spawn run. Nonetheless, the former treatment did not differ significantly from the latter and thus these two treatments were found to be significantly superior over the rest of treatments. Application of indole-3-acetic acid (IAA) 15 ppm, IAA 20 ppm, indole-3-butyric acid (IBA) 15 ppm and IBA 20 ppm was the subsequent best set of treatments in hastening the spawn run, which required 15 days for full spawn run. Spawn run period with the micronutrient mixture and untreated control was prolonged considerably. Micronutrients at all the concentrations of 1,2 and 5 ppm took 18 days for completion of spawn run, whereas untreated control took 18.5 days. Days required for completion of spawn run with various treatments of micronutrient and control differed non-significantly from each other. Thus, micronutrients evidently proved to be ineffective in lowering the spawn run period.

Pal et al., (2013) found that gibberellic acid treated substrate required less (10.83 days) period for spawn run in $P$. eous. Furthermore, earlier scientists also have reported the role of growth regulators in enhancing mycelial growth of range of edible mushrooms (Shukla, 1995; Bhardwaj, 2004; Guo et al., 2009; Pani, 2011; Uddin et al., 2012; Atri et al., 2013; Atri and Guleria, 2013). Thus, results of the present study are in agreement with those of these investigators.

\section{Days required for pinhead formation}

Data in respect of effect of various growth regulators and micronutrients on days required for pinhead formation in Pleurotus sajor-caju, portrayed in Table 2, indicated significantly 
varied response of growth regulators and micronutrients, tried at different concentrations.

Number of days required for pinhead formation with different treatments of growth regulators and micronutrients varied from 16 to 21.5 days. However, amongst the various treatments of growth regulators and micronutrients, application of gibberellic acid (GA) at the concentration of $20 \mathrm{ppm}$ conspicuously showed its effectiveness over the other treatments, as this treatment significantly shortened the period for pinhead formation. Pinheads in this treatment appeared on 16.00 days after spawning. This treatment was followed non-significantly by GA 15 ppm, which took 16.5 days for pinhead appearance. Consequently, these two treatments were statistically at par with each other and were found significantly superior over the rest of the treatments. Indole-3-acetic acid (IAA) 15 ppm, IAA 20 ppm, indole-3butyric acid (IBA) 15 ppm and IBA 20 ppm were the next best treatments, which took 18 days for pinhead formation. Pinhead appearance was prolonged considerably with micronutrients and untreated control. Micronutrients at 1,2 and 5 ppm concentrations required 21 days for pinhead formation, whereas untreated control treatment took 21.5 days. However, days taken for pinhead formation in micronutrient treatments differed non-significantly from those in control. Thus, micronutrient at all the three concentrations evidently was found to be ineffective in hastening pinhead formation.

In the present investigation, gibberellic acid at 20 as well as at 15 ppm hastened the spawn run, which might have reflected in speeding the pinhead appearance. Mohpatra and Behera (2013) obtained early pinning with IAA @ $200 \mathrm{ppm}$ in Volvariella volvacea. Furthermore, Dey et al., (2011) reported that the least number of days (13.6) were required from casing to primordial initiation in the treatment of $100 \mathrm{ppm} \mathrm{GA}_{3}$ in button mushroom. These results validate results of the present investigation.

\section{Days required for first harvest}

Results abridged in Table 2 relating to days required for first harvest of sporophores of Pleurotus sajor-caju, evidently suggested that the growth regulators and micronutrients, sprayed at different concentrations, had significant influence on the period required for first harvest of sporophores. Days required for first harvest of sporophores with various treatments varied significantly from 18.5 to 23.5 days.

Growth regulators and micronutrients, tried at different concentrations, showed considerable variation in their effectiveness to hasten the first harvest of sporophores. Amongst the various growth regulators and micronutrients tried in the present study, application of gibberellic acid (GA) at the concentration of $20 \mathrm{ppm}$ significantly required the lowest number of days (18.5) for the first flush of sporophores. This treatment was followed non-significantly by application of GA at 15 ppm, which required 19 days for the first harvest. However, the latter treatment differed non-significantly from the former and thus, these treatments were found to be statistically at par with each other and significantly superior over the rest of treatments in reducing the period required for the first harvest of sporophores. Indole-3-acetic acid (IAA) 15 ppm, IAA 20 ppm, indole-3-butyric acid (IBA) $15 \mathrm{ppm}$ and IBA $20 \mathrm{ppm}$ were the next best treatments, which required 20.5 days for the first harvest of sporophores. However, the first crop of sporophores was prolonged substantially with the treatments of micronutrients and untreated control. Micronutrients at 1,2 and $5 \mathrm{ppm}$ concentrations and untreated control treatment 
took 23.5 days for the first harvest. The results, thus, clearly substantiated the ineffectiveness of micronutrients in reducing period required for the first crop of sporophores.

\section{Total yield of sporophores}

Data presented in Table 3 in regard to total yield of sporophores of Pleurotus sajor-caju per $1000 \mathrm{~g}$ dry weight of substrate, revealed significantly varying response of growth regulators and micronutrients experimented at different concentrations.

Growth regulators and micronutrients appraised at different concentrations showed clear variation in total yield of sporophores of P. sajor-caju. However, spraying of gibberellic acid (GA) 20 ppm gave significantly highest yield of sporophores to the extent of $858.25 \mathrm{~g}$. Thus, spraying of GA $20 \mathrm{ppm}$ was the most effective treatment, which yielded $20.30 \%$ increase in yield over untreated control. GA @ 15 ppm was the next best treatment in improving total yield of sporophores, which produced $855.00 \mathrm{~g}$ sporophores. However, total sporophore yield obtained in these two treatments differed nonsignificantly from each other, which clearly indicated that these two treatments had equality in their efficiency in enhancing sporophore yield of Pleurotus sajor-caju. Thus, application of GA at 20 and $15 \mathrm{ppm}$ were the superior treatments in augmenting the yield. Indole -3-acetic acid (IAA) $20 \mathrm{ppm}$, IAA 15 ppm and indole -3- butyric acid (IBA) 20 ppm were the next best treatments, in order of efficacy, in enhancing the sporophore yield. The least sporophore yield was obtained in untreated control beds. However, yield obtained with micronutrients, at all the concentrations of 1,2 and $5 \mathrm{ppm}$, differed non-significantly from that obtained in control. Thus, micronutrients at all the concentrations proved ineffective in enhancing the sporophore yield.

\section{Biological Efficiency}

Data presented in Table 3 in regard to per cent biological efficiency (BE) of Pleurotus sajor$c a j u$, revealed significantly varying response of plant growth regulators and micronutrients experimented at different concentrations.

Growth regulators and micronutrients appraised at different concentrations showed clear variation in $\mathrm{BE}$ of $P$. sajor-caju. However, spraying of gibberellic acid (GA) 20 ppm recorded significantly highest $\mathrm{BE}$ to the extent of $85.83 \%$. GA @ 15 ppm was the next best treatment in improving BE, which was to the tune of $85.50 \%$. Nevertheless, BE noted with these two treatments differed nonsignificantly from each other, which clearly indicated that these two treatments had equality in their efficiency in enhancing BE. Thus, application of GA at 20 and $15 \mathrm{ppm}$ were the superior treatments, in comparison to the rest, in augmenting $\mathrm{BE}$. Indole -3-acetic acid (IAA) 20 ppm, IAA 15 ppm and indole 3- butyric acid (IBA) $20 \mathrm{ppm}$ were the next best treatments, in order of efficacy, in enhancing BE. The least BE was obtained in untreated control treatment. However, BE estimated with micronutrients, at all the concentrations of 1,2 and 5 ppm, differed non-significantly from that obtained in control. Thus, micronutrients at all the concentrations proved ineffective in enhancing BE. 
Table.1 Influence of growth regulators and micronutrients on in vitro colony diameter of $P$. sajor-caju

\begin{tabular}{|c|c|}
\hline Treatment details & Colony diameter $(\mathrm{mm})$ \\
\hline T1: Gibberellic Acid (GA) 10 ppm & 80.32 \\
\hline T2: Gibberellic Acid (GA) 15 ppm & 89.98 \\
\hline T3: Gibberellic Acid (GA) 20ppm & 90.00 \\
\hline T4: Indole-3-Acetic Acid (IAA) 10 ppm & 60.50 \\
\hline T5: Indole-3-Acetic Acid (IAA) 15 ppm & 70.90 \\
\hline T6: Indole-3-Acetic Acid (IAA) 20 ppm & 80.70 \\
\hline T7: Indole-3-Butyric Acid (IBA) 10 ppm & 70.95 \\
\hline T8: Indole-3-Butyric Acid (IBA) 15 ppm & 80.45 \\
\hline T9: Indole-3-Butyric Acid (IBA) 20 ppm & 80.60 \\
\hline T10: Micronutrient Mixture 1 ppm & 80.00 \\
\hline T11: Micronutrient Mixture 2 ppm & 70.80 \\
\hline T12: Micronutrient Mixture 5 ppm & 70.90 \\
\hline T13: Control & 50.00 \\
\hline S.E. $(\mathbf{m}) \pm$ & 0.01 \\
\hline CD at $1 \%$ & 0.04 \\
\hline
\end{tabular}

Table.2 Influence of growth regulators and micronutrients on days required for spawn run, pinhead formation and first harvest in Pleurotus sajor-caju

\begin{tabular}{|c|c|c|c|}
\hline Treatment details & $\begin{array}{c}\text { Number of days } \\
\text { required for } \\
\text { spawn run }\end{array}$ & $\begin{array}{c}\text { Number of days } \\
\text { required for } \\
\text { pinhead } \\
\text { formation }\end{array}$ & $\begin{array}{c}\text { Number of days } \\
\text { required for } \\
\text { first harvest }\end{array}$ \\
\hline T1: Gibberellic Acid (GA) 10 ppm & 16.50 & 19.50 & 22.00 \\
\hline T2: Gibberellic Acid (GA) 15 ppm & 13.50 & 16.50 & 19.00 \\
\hline T3: Gibberellic Acid (GA) 20ppm & 13.00 & 16.00 & 18.50 \\
\hline T4: Indole-3-Acetic Acid (IAA) 10 ppm & 16.50 & 19.50 & 22.00 \\
\hline T5: Indole-3-Acetic Acid (IAA) 15 ppm & 15.00 & 18.00 & 20.50 \\
\hline T6: Indole-3-Acetic Acid (IAA) 20 ppm & 15.00 & 18.00 & 20.50 \\
\hline T7: Indole-3-Butyric Acid (IBA) 10 ppm & 16.50 & 19.50 & 22.00 \\
\hline T8: Indole-3-Butyric Acid (IBA) 15 ppm & 15.00 & 18.00 & 20.50 \\
\hline T9: Indole-3-Butyric Acid (IBA) 20 ppm & 15.00 & 18.00 & 20.50 \\
\hline T10: Micronutrient Mixture 1 ppm & 18.00 & 21.00 & 23.50 \\
\hline T11: Micronutrient Mixture 2 $\mathbf{~ p p m}$ & 18.00 & 21.00 & 23.50 \\
\hline T12: Micronutrient Mixture 5 ppm & 18.00 & 21.00 & 23.50 \\
\hline T13: Control & 18.50 & 21.50 & 23.50 \\
\hline S.E. (m) $\mathbf{m}$ & 0.47 & 0.48 & 0.49 \\
\hline CD at 5\% & 1.39 & 1.40 & 1.42 \\
\hline
\end{tabular}


Table.3 Total yield and biological efficiency of Pleurotus sajor-caju as influenced by various growth regulators and micronutrients

\begin{tabular}{|c|c|c|}
\hline Treatment details & $\begin{array}{c}\text { Total sporophore } \\
\text { yield }(\mathbf{g})\end{array}$ & $\begin{array}{c}\text { Biological } \\
\text { efficiency (\%) }\end{array}$ \\
\hline T1: Gibberellic Acid (GA) 10 ppm & 754.22 & 75.42 \\
\hline T2: Gibberellic Acid (GA) 15 ppm & 855.00 & 85.50 \\
\hline T3: Gibberellic Acid (GA) 20ppm & 858.25 & 85.83 \\
\hline T4: Indole-3-Acetic Acid (IAA) 10 ppm & 750.00 & 75.00 \\
\hline T5: Indole-3-Acetic Acid (IAA) 15 ppm & 792.41 & 79.24 \\
\hline T6: Indole-3-Acetic Acid (IAA) 20 ppm & 804.89 & 80.49 \\
\hline T7: Indole-3-Butyric Acid (IBA) 10 ppm & 746.58 & 74.66 \\
\hline T8: Indole-3-Butyric Acid (IBA) 15 ppm & 763.05 & 76.31 \\
\hline T9: Indole-3-Butyric Acid (IBA) 20 ppm & 769.28 & 76.93 \\
\hline T10: Micronutrient Mixture 1 ppm & 715.54 & 71.55 \\
\hline T11: Micronutrient Mixture 2 ppm & 716.80 & 71.68 \\
\hline T12: Micronutrient Mixture 5 ppm & 717.84 & 71.78 \\
\hline T13: Control & 713.43 & 71.34 \\
\hline S.E. $(\mathbf{m}) \pm$ & 1.68 & 0.17 \\
\hline CD at 5\% & 4.91 & 0.48 \\
\hline
\end{tabular}

Many researchers have observed increase in yield of mushroom owing to use of growth regulators. Shukla (1995) found that indole butyric acid @ 5 and 10 ppm induced maximum number of sporophores in Lentinus edodes. Eswaran and Ramabadran (2000) reported that GA at $100 \mathrm{ppm}$ was the best growth regulator in enhancing the yield of $P$. eous. Increase in weight of fruiting body, total yield and biological efficiency of the $P$. ostreatus with increase in the concentration of $\mathrm{GA}_{3}$ was recorded by Rostum (2010). Size and number of mushrooms as well as yield of Calocybe indica was found to be increased by spraying $50 \mathrm{ppm} \mathrm{GA}_{3}$ on the emerging primordia (Pani, 2011). The highest yield of Pleurotus eous has been reported in gibberellic acid incorporated medium. (Pal et al., 2013). Sarker and Chowdhury (2013) found that the use of $\mathrm{GA}_{3}$ at $10 \mathrm{ppm}$ had a significant effect on biological yield, economic yield and dry economic yield of oyster mushroom. Mohapatra and Behera (2013) found that IAA @ 200 ppm increased the yield in $V$. volvacea to an extent of 22.12 $\%$ in comparison to control. Krishnamoorthy and Balan (2015) found increase in yield of milky mushroom with the use of $\mathrm{GA}_{3}$ at 40 ppm. Kaur (2016) obtained maximum yield of $C$. indica with spray of GA at pinning and at all stages. Results of the present investigations are in agreement with the results of these scientists.

\section{References}

Anonymous, 2018. In: Horticultural Statistics at a Glance 2018 Pub.: Govt. of India, Ministry of Agriculture and Farmers' Welfare, Department of Agriculture, Cooperation and Farmers' Welfare, Horticulture Statistics Division, pp.10.

Atri, N. S. and Guleria, L., 2013. Evaluation of vitamins, phytohormones and trace element requirements of Lentinus cladopus Lev. Int. J. Pharm. Pharm. Sci.5 (4): 40-42.

Atri, N. S., Kumari, B., Singh, R. and 
Upadhyay, R. C., 2013. Effect of vitamins and growth regulators on vegetative growth of Lentinus squarrosulus. Mycosphere, pp. 10801090.

Bhardwaj, G., 2004. Studies on Calocybe indica (P. \& C.) - The milky mushroom. Ph.D. (Agri.) thesis submitted to Dr. Yashwant Singh Parmar University of Horticulture and Forestry, Nauni, Solan-173230 (H.P.), India.

Chadha, K. L., 1992. Mushroom research and developments in India. Mush. Res. 1: 112.

Charles, R., 1986. Effects of growth regulators compounds on yield and size of the commercial mushroom, Agaricus bisporus. Proc Int'l. Sym. Scientific and Technical Aspects of cultivating edible fungi. The Penna. State Univ. USA.

Chodchoi, C., 1986. Effects of growth regulators compounds on yield and size of the commercial mushroom (Auricularia polytricha). Proceeding of the $24^{\text {th }}$ national Congress Bangkok, pp. 127-134.

Dey, B. C., Hossain, M. M., Akanda, A. M. Kamruzzaman, M., Zakaria, M., Choudhary, M. B. K. and Sarker, N. C., 2011. Effect of different plant growth regulators on the yield and yield attributes of white button mushroom. Bangladesh J. Mushroom. 5(1): 35-41.

Eswaran, A. and Ramabadran, R., 2000. Studies on some physiological, cultural and postharvest aspects of oyster mushroom, Pleurotus eous (Berk.) sacc. Tropical Agricultural Research. 12: 360-374.

Garcha, H. S. and Kalra, K. L., 1979. Spawn production and its viability. Indian $J$. Microbiol.19(4): 214-216.

Guo, X., Zou, X. and Sun, M., 2009. Effects of phytohormones on mycelial growth and exopolysaccharide biosynthesis of medicinal mushroom Pellinus linteus. Bioprocess Biosyst Eng. 32: 701-707.

Kaur, R., 2016. Effect of growth regulators on biomass production and yield potential of milky mushroom Calocybe indica (P \& C). M.Sc. (Agri.) thesis submitted to Punjab Agricultural University, Ludhiana, Punjab.

Krishnamoorthy, A. S. and Balan, V., 2015. A comprehensive review of tropical milky white mushroom (Calocybe indica P \& C). Mycobiology. 43 (3): 184-194.

Kulshreshtha, M., Singh, A. and Vipul, D., 2009. Effect of drying condition on mushroom quality. Journal of Engineering Science and Technology. 4(1): 90-98.

Maniruzzaman, M., 2004. Influence of media composition and growth regulators on mycelial growth and spawn production of three mushroom species. MS Thesis, Department of Biotechnology, BAU, Mymensingh.

Mohapatra, K. B. and Behera, B., 2013. Influence of plant growth regulators on biological efficiency of straw mushroom, Volvariella volvacea. Mushroom Research. 21(1): 59-61.

Mukhopadhyay, R., Chatterjee, S., Chatterjee, B. P. and Guha, A. K., 2005. Enhancement of biomass production of edible mushroom Pleurotus sajor-caju by plant growth hormones. Process Biochem.40(3): 1241-44.

Pal, D. P., Mishra, S. P., Shukla, C. S. and Verma, L. R., 2013. Effect of growth regulators on mycelia growth and yield of Pleurotus eous. International Journal of Agricultural Sciences. 10(1): 151-153.

Pandey, R. S. and Ghosh, S. K., 1996. A Handbook on Mushroom Cultivation, Emkay publications Delhi, pp. 134. 
Pani, B. K., 2011. Influence of some growth regulators on biomass production and sporophore yield of milky mushroom (Calocybe indica). Asian J. Exp. Biol. Sci. 2(2): 328-331.

Panse, V. G. and Sukhatme, P. V., 1985. Statistical Methods for Agriculture Workers. ICAR Publ. New Delhi. 3rd Edn., pp.347.

Prajapati, S., Jamkar, T., Singh, O. P., Raypuriya, N., Mandloi, R. and Jain, P. K., 2015. Plant Growth regulators in vegetable production: an overview. Plant Archives. 15: 619-626.

Rostum, A. N., 2010. Use of some growth regulators to improve yield, storage life, and medicinal properties of oyster mushroom. The Iraqi Journal of Agricultural Sciences. 41(6): 48-60.

Sarker, R. R. and Chowdhury, A. K. M. S. H., 2013. Effect of different doses of $\mathrm{GA}_{3}$ application at primordia initiation stage on the growth and yield of oyster mushroom. J. Bangladesh Agril. Univ.11(1): 5-10.

Shukla, A. N., 1995. Effect of hormones on the production of Shiitake. Lentinus edodes (Bark.) Sing. Mushroom Research. 4: 39-42.

Singh, S. D. and Prasad, G., 2012. Effect of different substrate supplements on the growth and yield of two species of Mushroom Pleurotus florida and $P$. sajor-caju. International Multidisciplinary Research Journal. 2(3): 61-64.

Uddin, M. J., Nasiruddin, K. M., Haque, M. E., Biswas, A. K. and Islam, M. S., 2012. Influence of different media, variety and growth regulator on mycelia colony proliferation of mushroom. J. Environ. Sci. \& Natural Resources. 5(1): $223-227$.

\section{How to cite this article:}

Godse, D. D., C. T. Kumbhar, A. C. Jadhav and Shitole, L. S. 2021. Effect of Growth Regulators and Micronutrients on Growth and Yield of Pleurotus sajor-caju. Int.J.Curr.Microbiol.App.Sci. 10(12): 240-250. doi: https://doi.org/10.20546/ijcmas.2021.1012.028 